\title{
Sealyham Terrier
}

National Cancer Institute

\section{Source}

National Cancer Institute. Sealyham Terrier. NCI Thesaurus. Code C53730.

The Sealyham Terriers have a large nose and powerful jaws with very long canines. Its front legs are short and straight; the hind legs are powerful and muscular. The coat is bristly, coarse, and long and comes in white or yellowish-white. Height: Not more then 12 inches (30 cm.) Weight: Maximum 20 pounds $(9 \mathrm{~kg}$.) 